\title{
Diachronic Study of the Vegetation Covers Spatiotemporal Change Using GIS and Remote Sensing in the Ferkla Oasis: Case Study, Bour El Khourbat, Tinjdad, Morocco
}

\author{
Meryem El Amraoui1 ${ }^{*}$, Lahcen Kabiri' ${ }^{1}$ Amina Kassou', Lamya Ouali1 ${ }^{1}$, Alexis Nutz ${ }^{2}$ \\ ${ }^{1}$ Department of Geosciences, Geo-Resource-Geo-Environment-Geological patrimony and Oasis Heritage Research Team, Faculty \\ of Sciences and Techniques of Errachidia, Moulay Ismail University, Boutalamine-Errachidia, Morocco \\ ${ }^{2}$ European Center for Research and Education in Environmental Geosciences, Aix Marseille University, Marseille, France \\ Email: *mery.elamraoui@edu.umi.ac.ma
}

How to cite this paper: El Amraoui, M., Kabiri, L., Kassou, A., Ouali, L., \& Nutz, A. (2022). Diachronic Study of the Vegetation Covers Spatiotemporal Change Using GIS and Remote Sensing in the Ferkla Oasis: Case Study, Bour El Khourbat, Tinjdad, Morocco. Journal of Geoscience and Environment Protection, 10, 173-188. https://doi.org/10.4236/gep.2022.101012

Received: December 21, 2021

Accepted: January 23, 2022

Published: January 26, 2022

Copyright $\odot 2022$ by author(s) and Scientific Research Publishing Inc. This work is licensed under the Creative Commons Attribution International License (CC BY 4.0).

http://creativecommons.org/licenses/by/4.0/ (c) (i) Open Access

\begin{abstract}
The Oasis of Ferkla is part of the Oases of Tafilalt in southern Morocco. These are classified by UNESCO as the Oases of Southern Morocco Biosphere Reserve. The Ferkla Oasis is increasingly experiencing a situation of increased regression and degradation, aggravated by the effects of climate change. These foreshadow a considerable acceleration of desertification and drought with the effect of the loss of production systems whose social, ecological and economic role remains major for the whole country. In order to contribute to a better understanding of the dynamics of the vegetation in this territory and the impact of climate change in the Oasis of Ferkla, we used spatial remote sensing to trace the evolution of changes in the vegetation cover in an agricultural extension called Bour El Khourbat. Calculation of the Normalized Difference Vegetation Index for seven multidate satellite images allowed us to follow the vegetation in this oasis zone from the year 1984 to 2019. Indeed, from these multi-temporal images, this study clearly shows the evolution of the vegetation with a remarkable agricultural extension towards the South-East of the zone. This extension is due not only to the installation of a diversion dam upstream but also to the development of the localized irrigation system "Drop by Drop" which is a technique that saves water resources in addition to the presence in the area. Bour El Khourbat specifies a geological structure, in the primary, relatively favorable to having water linked to cracks.
\end{abstract}

\section{Keywords}

Climate Change, Remote Sensing, GIS, Vegetation Change Detection, Ferkla Oasis 


\section{Introduction}

The Oasis of Ferkla is part of the Oases of Tafilalt, in southern Morocco, which have been recognized by United Nations Educational, Scientific and Cultural Organization (UNESCO) as a Biosphere Reserve of the Oases of Southern Morocco (RBOSM) since 2000. The few environmental diagnoses and reports carried out by national or even international organizations have identified several worrying developments in this Oasis. These include the drying out of date palms, soil degradation, silting up, loss of agricultural productivity and alteration of agro-biodiversity. The system is strongly influenced by climate change (Kabiri, 2005). The origin of the water resource in this region was distributed until the end of the 1990s as follows: $61 \%$ perennial, 30\% underground and $9 \%$ from floods (Margat, 1958). Since this period, in response to the decrease in precipitation, it is almost exclusively coming from underground origin with only rare inflows of surface water from floods, increasingly rare, in mountainous areas at certain times of the year. At the same time, towards the end of the 1970s, the Lkhorbat palm grove has been extended outside the traditional Oasis boundaries (Kabiri, 2005), towards the locality known as "Bour El Khourbat" as a result of intense investment in agriculture, particularly by those families with immigrants in Europe. This has resulted in the intense multiplication of motor pumps, increasingly modern and much more powerful with flow rates of up to 90 1/s (Margat, 1958; Ruhard, 1977; Boudad \& Kabiri, 2002; Kabiri, 2005).

Finally, the combined effect of overexploitation and the food deficit during the 1990s caused a dramatic drop in the alluvial water table. Since this period, the farmers of Bour El Khourbat have found themselves facing a shortage of water for their agricultural activity.

Through this work, we reconstruct the evolution of the vegetation cover in the oasis of Bour El Khourbat between 1984 and 2019 using the Normalized Difference Vegetation Index (NDVI) vegetation index method. Then, we discuss this evolution in relation to the climate change that the region is experiencing and the change in the use of water resources in the Oasis environment. This work aims to better understand the respective impact of climate change and management practices on water resources in these stressed oasis systems.

\section{Study Area}

The Bour El Khourbat study area constitutes the upstream extension of the El Khourbat palm grove, both belonging to territory of the municipality of Ferkla El Oulia. This collectivity is bounded by the territorial collectivities of Ferkla Essoufla of Aghbalou N'Kardous in the North and Tinjdad in the South, that of Alnif in the West and Taghazoute N'Ait Atta and Ait El Ferssi in the East by the rural commune of Melaab (Figure 1).

\subsection{Physical Context}

Bour El Khourbat is located in the Eastern Anti Atlas, between the Ougnat in the 

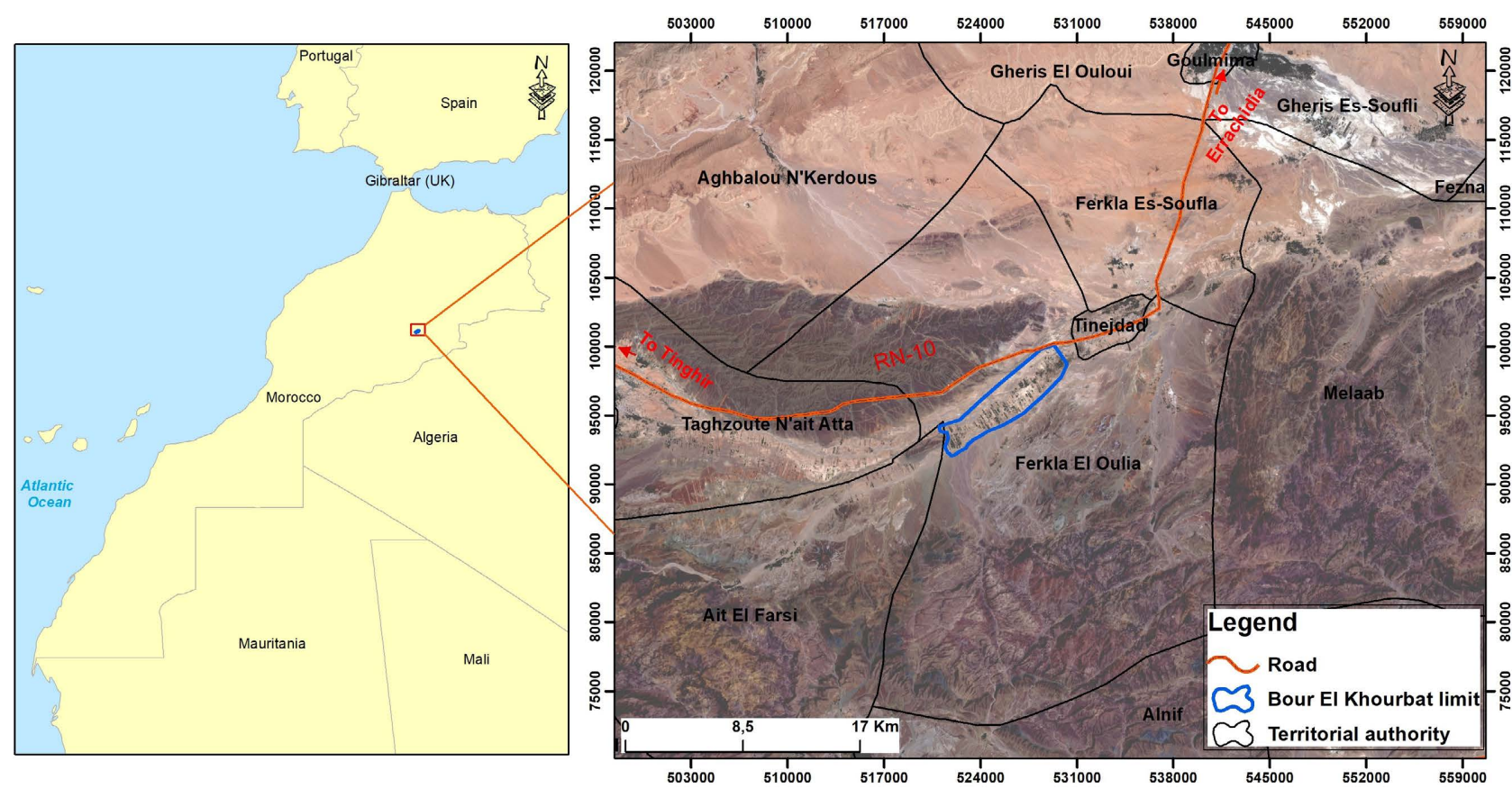

Figure 1. Geographical location map of the Bour El Khourbat study area.

east and Saghro in the west (Du Dresnay et al., 1988). It is located between the Precambrian and Primary massifs of the Eastern Anti-Atlas to the south and the Cretaceous formations of the pre-African furrow, Cretaceous Errachidia basin, to the north (Baki et al., 2016). The northern limit of this furrow with the High Atlas, with carbonate rocks of Jurassic age, is materialized by the great South Atlas accident. The Ferkla Oasis is developed on a floodplain made up of sandy-silty to sandy loam alluvial sediments with sometimes continental carbonate deposits (Margat, 1958; Ruhard, 1977; Boudad \& Kabiri, 2002).

\subsection{Demographic Context}

The total population of the territorial collectivity of Ferkla El Oulia increased from 18,889 in 1994, to 20,214 in 2004 and 22,722 in 2014 (RGPH, 2014). This population is spread over 23 ksour which are mainly distributed along the rivers (the Oued). The Ksour El Khourbat, Tamrdoulte and Ait Assem have the highest population. Currently the population of Bour El Khourbat is 1125 people (RGPH, 2014).

\subsection{Climate Context}

\subsubsection{Precipitation}

The region's climate is characterized by low precipitation and very irregular in weather (Figure 2). The average annual precipitation values vary between 50 and $300 \mathrm{~mm}$. Between 1980 and 1988, rainfall was very low (drought years). Also, in the late 1990s, precipitation fell even more. Between 2005 and 2010, precipitation experienced a significant increase. Between 2010 and 2018, the area became less rainy. The inter-annual average rainfall map between 1975 and 2013 shows 


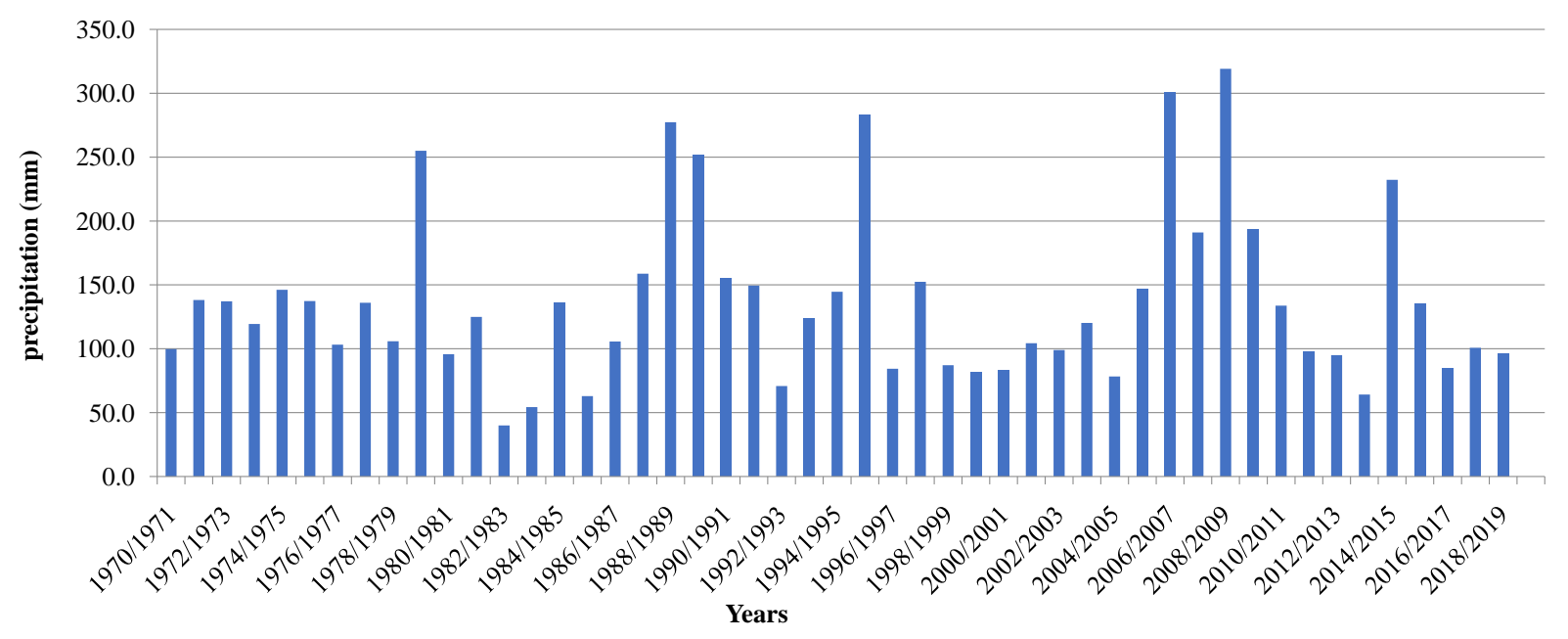

Figure 2. Evolution of annual average precipitation between 1970 and 2019.

a low rainfall of around $100 \mathrm{~mm} /$ year which affects the study area (Figure 3).

At the same time, temperatures vary from $5^{\circ} \mathrm{C}$ in winter to over $44^{\circ} \mathrm{C}$ in summer, indicating a significant seasonal variation. The average annual temperature, around $23^{\circ} \mathrm{C}$, is relatively high and contributes to the aridity of the climate. It appears that July is the hottest and January is the coldest.

\subsubsection{Temperature}

At the same time, temperatures vary from $5^{\circ} \mathrm{C}$ in winter to over $44^{\circ} \mathrm{C}$ in summer, indicating a significant seasonal variation. The average annual temperature, around $23^{\circ} \mathrm{C}$, is relatively high and contributes to the aridity of the climate. It appears that July is the hottest and January is the coldest.

\subsection{Hydrological Context}

Bour El Khourbat is located in the Rheris watershed and more precisely in the Toudgha-Ferkla sub-basin. Its altitude is around $1000 \mathrm{~m}$. It is considered as a zone of confluence of the two main revers which are the Oued Satt, of anti-Atlas origin, in the South and the Oued Ferkla, of High Atlas origin, in the North (Figure 4).

The annual flow regime is characterized by two seasons of high water (in the form of flood), autumn and spring, separated by two low-flow seasons, winter and summer, during which the flow is very low and captured completely upstream (Figure 5).

The Oueds regime is characterized by low flows, often non-existent. However, sometimes, they can be very strong in the form of episodic short-lived floods which originate especially at the level of the central high atlas as it was recorded in the station of Bouijane on wadi Toudgha (Ferkla downstream) during the year 1989-1990 where the flow reached about $2400 \mathrm{~m}^{3} / \mathrm{s}$ in 2008 when it was over $250,000 \mathrm{~m}^{3} / \mathrm{s}$ (Figure 6). These waters, along with those from the summits of the Saghro, constitute the main surface resources of this locality.

Currently, the origin of the water resource in this locality is almost exclusively 


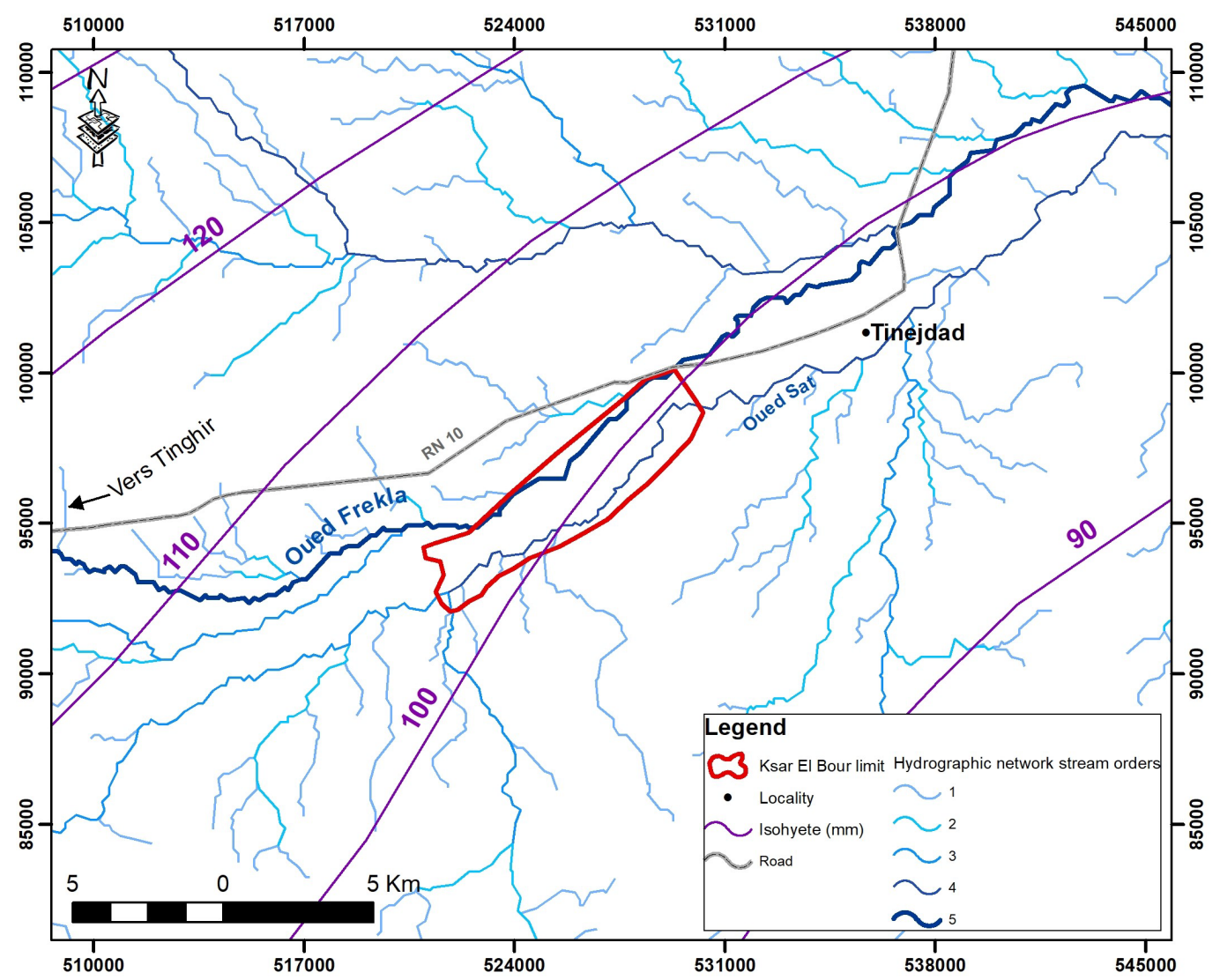

Figure 3. Map of isohyets of inter-annual mean rainfall between 1975 and 2013.

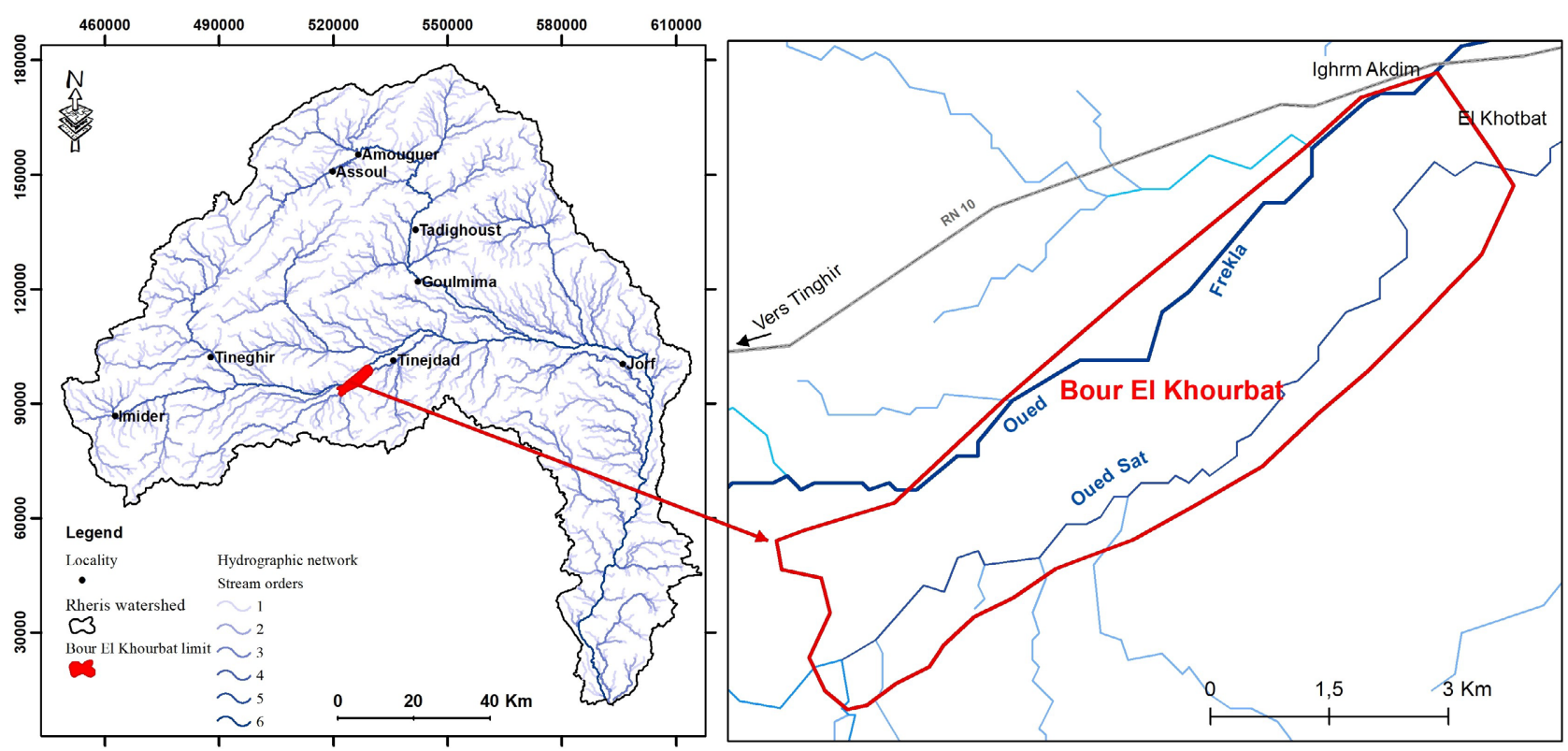

Figure 4. Hydrographic network of the study area.

underground and comes from the only Quaternary aquifer that spreads over the Ferkla plain along the two main Wadis and particularly along the Ferkla Wadi. It is supplied mainly by the High Atlas through infiltration and flood waters. Part 


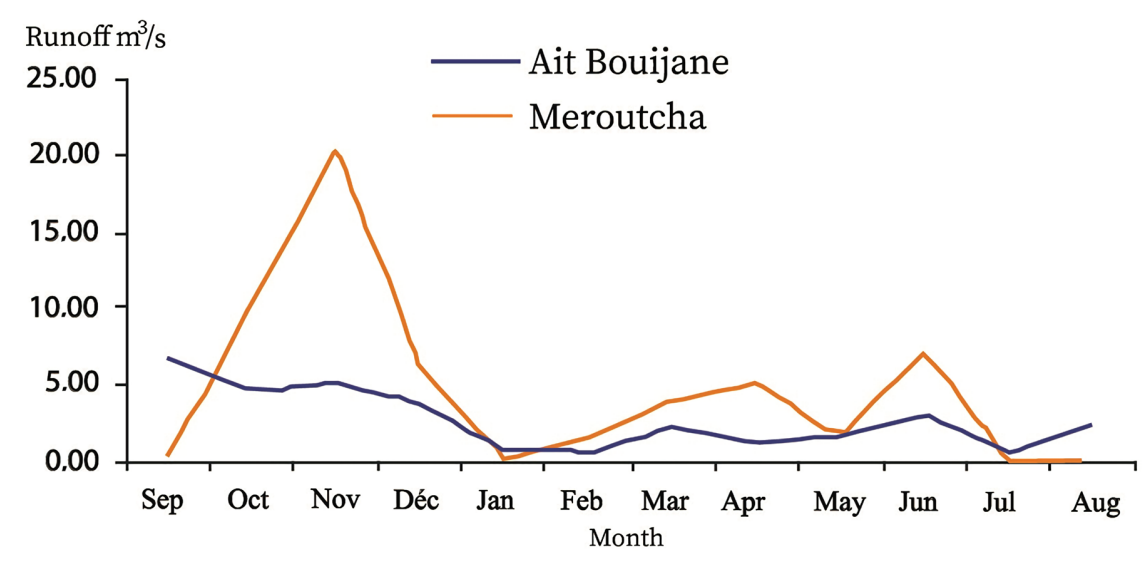

Figure 5. Average monthly flows $\left(\mathrm{m}^{3} / \mathrm{s}\right)$ of Oued Toudgha (1982/2002) (ABHGZR, 2011).

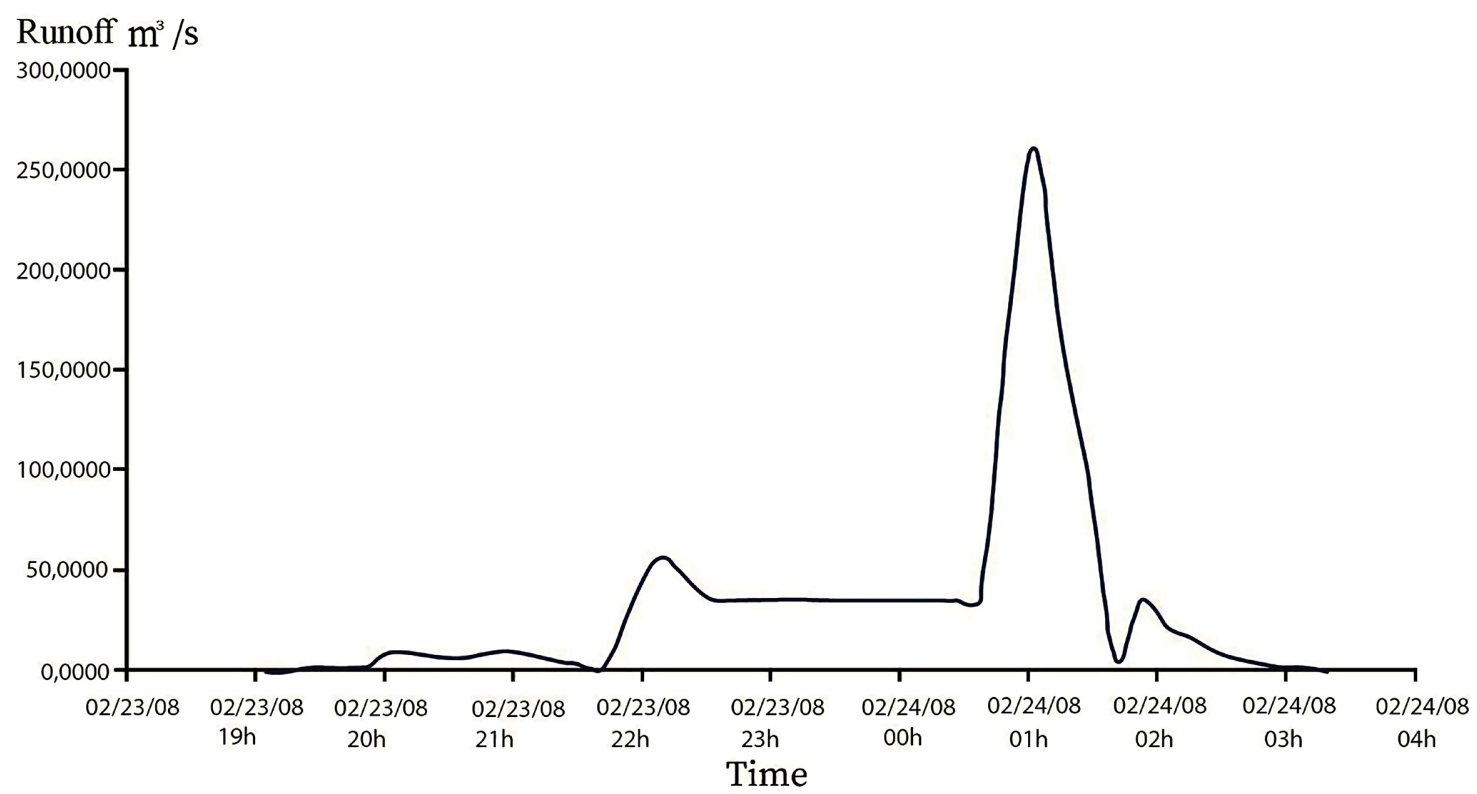

Figure 6. Hydrograph of the floods of the AitBouijane station (IRE 355/55) (ABHGZR, 2011).

of the water can also come from altered and fractured zones of the geological formations of the Primary and in particular those of the Ordovician of the Anti-Atlas in contact (or at the limit) with the formations of the Quaternary (Margat, 1958; Ruhard, 1977; Baki et al., 2016).

\subsection{Water Management}

Regarding the mobilization of water resources, surface water is used for irrigation thanks to the various diversion thresholds built along the Wadis like the one built upstream from Bour El Khourbat on Oued Ferkla allowing diverting water to the palm groves using a network of complex irrigation canals that run through the area.

In addition to using surface water, farmers mainly exploit groundwater from the Quaternary water table alone through wells and recently boreholes.

Historically, around the 1950s and up to the early 1970s of the last century, 
farmers in the area collectively exploited groundwater through cooperatives "Collective well dug by the agricultural services in 1956". The mobilization of this water is done thanks to the metric to kilometric irrigation canals known as "the Saguias" which make it possible to irrigate the new plots outside the Oasis (extension zone) on one hand and to strengthen those of the El Khourbat palm grove (traditional oasis) and other downstream oases on the other hand.

The availability of water and land aroused investment interests, indeed and from the seventies of the last century and with the arrival of funds from immigrants in France, the area has experienced significant investments in agriculture and we are witnessing the proliferation of individual wells which collect water at shallow depths at the beginning since the water table was still saturated. So, during this period, there is no shortage of water and the motor pumping is accentuated (Kabiri, 2005).

From the beginning of the 1980s, and with the drought that hit all of Morocco and in particular this area, already very vulnerable, there was a lack of water and the farmers proceeded to deepen their wells in search of water. All of them reached the Paleozoic sedimentary rocks that form the bedrock of the area. Because of this lack, several farmers abandoned their plots and others continued to deepen their wells but also to dig underground galleries (underground lakes) in schisto-sandstone geological formations, over lengths that sometimes exceed 20 $\mathrm{m}$. Despite this attachment of the population to their land, water is increasingly scarce and scarcity is setting in.

The end of 2004 saw the appearance of the localized irrigation system aimed at encouraging farmers to use this technique in order to reduce the pressure on water and its recovery and above all to ensure water for the farmers, crops during the summer period. Indeed, the "Drop by Drop" was initially installed in two pilot demonstration farms of 1.5 ha Bour El Khourbat.

It allowed encouraging peasants to invest in this water-saving irrigation technique. From now on, the farmers remaining in the zone continue to exploit the groundwater by using the Drop by Drop which is supported and subsidized by the Green Morocco plan. The region is seeing the emergence of geomembrane water storage basins which are also subsidized by the Moroccan state. The Drip technique is in fact, on the distribution of water in very small quantities, but with high frequencies, that is to say that the water is distributed according to the daily needs of the plant.

Subsequently, individual photovoltaic motor-pumping appeared in the area, which caused continuous withdrawals of the existing groundwater. This was having an impact on a few farmers who do not have solar energy. In fact, we are witnessing the drying up of a few wells that have still been functional so far, and the consequence is that other plots are being replenished. Thus, the total area of vegetation is affected and variable with time.

Between 2010 and 2018, the area, like other locations in this territory, experienced an increase in the number of wells and/or boreholes (Figure 7).

The data available on the piezometry of a few wells belonging to the region 


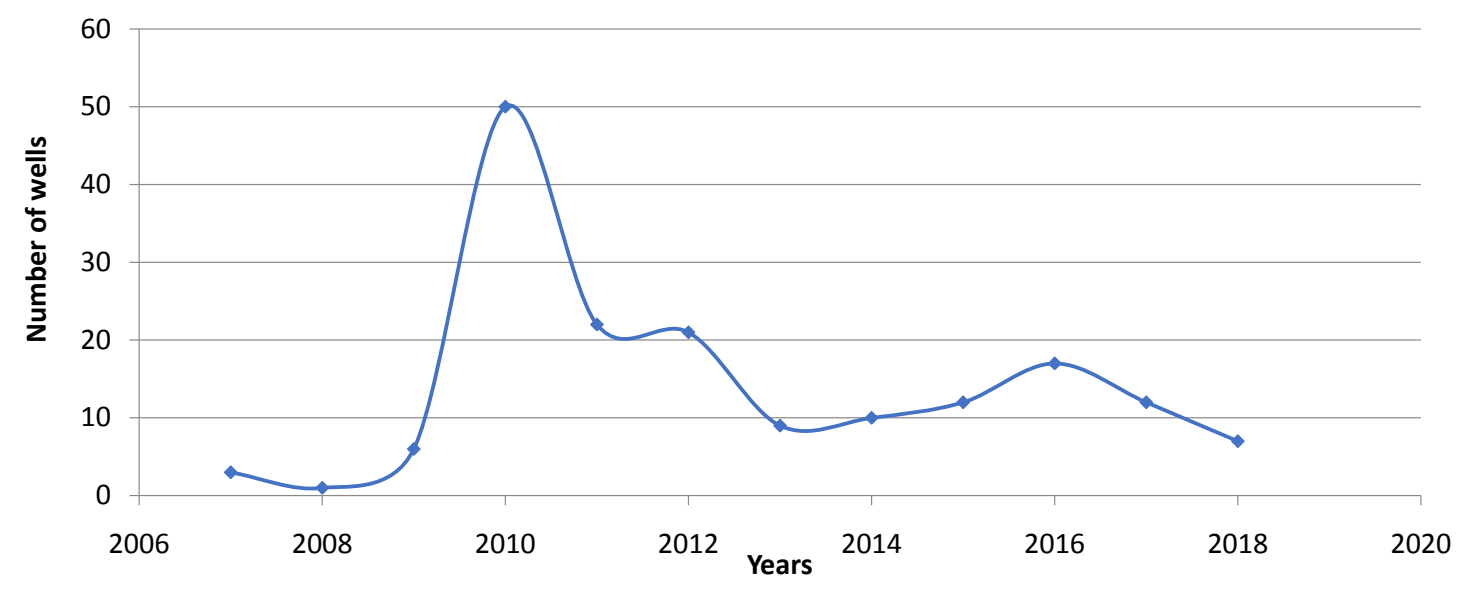

Figure 7. Evolution of the number of wells in the territory of the municipality of Ferkla El Oulia.

indicate that the water level is relatively stable in these wells between 2012 and 2018, (Figure 8).

This recorded increase is to be put, very probably, in relation to the launch in Morocco of the Green Morocco Plan in 2008. The evolution of the piezometric level of the quaternary water table of some wells in the area indicates that the water level is relatively low, stable in these wells between 2012 and 2018 (Figure 9).

In 2013 there was a strengthening of the irrigation system with the commissioning of the El Khourbat dam upstream of the area. The construction of this one played a very remarkable role in the extension of the plots towards the south-east of Bour El Khourbat.

Currently, the supply of the population of Bour El Khourbat which is 1125 (RGPH, 2014) with drinking water is done only through these wells and sometimes when this area is harmed by drought and due to months of very hot and dry weather, so the population was supplied by cisterns.

Farmers' water needs are increasingly important in a context of structural droughts and climate change. The areas of vegetation fluctuate according to natural conditions and human actions.

\section{Material and Methods}

\subsection{Data Base}

Our work was mainly based on the topographic map of Alnif $(1 / 50,000)$ as well as on seven multidate satellite images (Landsat 5 TM 1984, Landsat 5 TM-1990, Landsat 7 ETM-2000, Landsat 5 TM-2006, Landsat 8 OLI-2016, Landsat 8 OLI-2018 and Landsat 8 OLI-2019) to understand the evolution of land usage from 1984 to 2019.

\subsection{Methods}

The choice of dates for satellite images was made on the basis of their availability and visibility on the Earth Explorer websites as satellite sensors are usually exposed to atmospheric effects making viewing and interpreting the image 


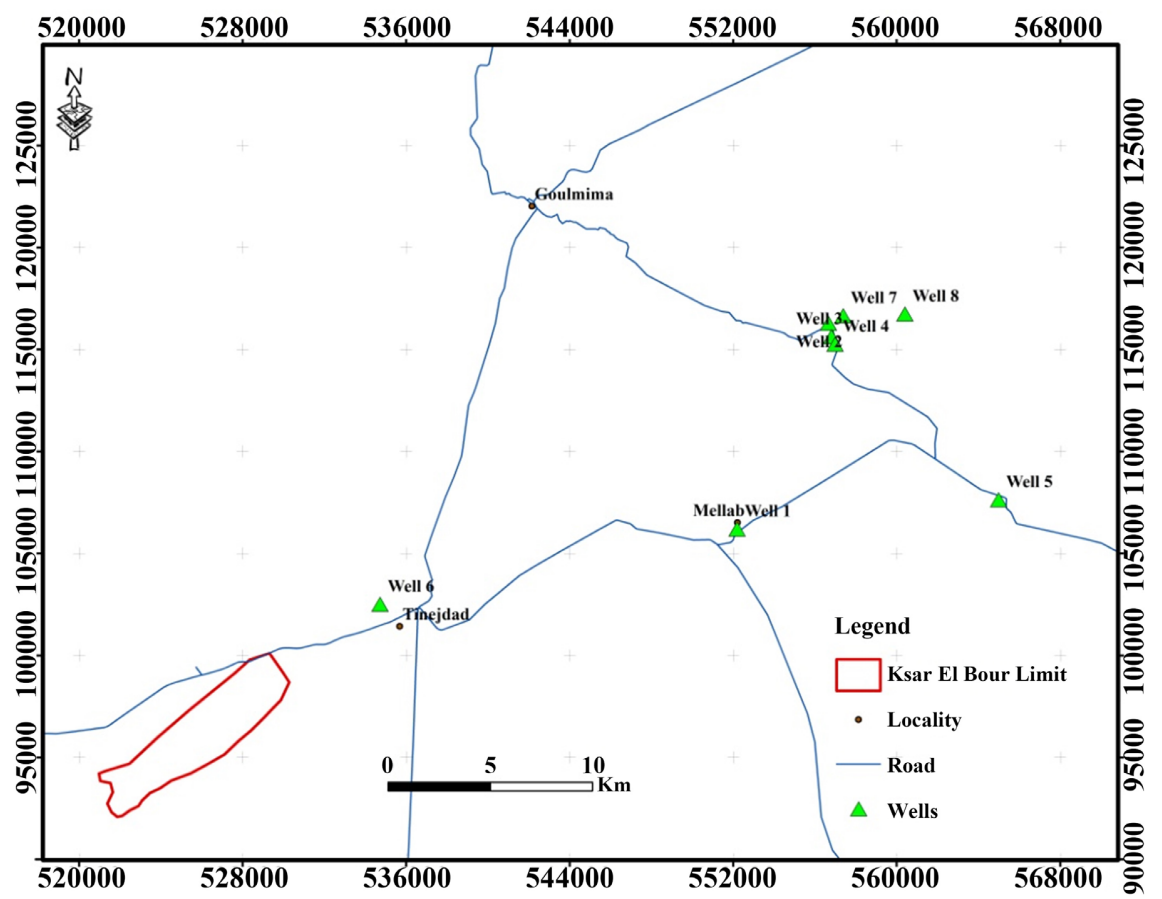

Figure 8. Location of a few wells capturing the quaternary water table.

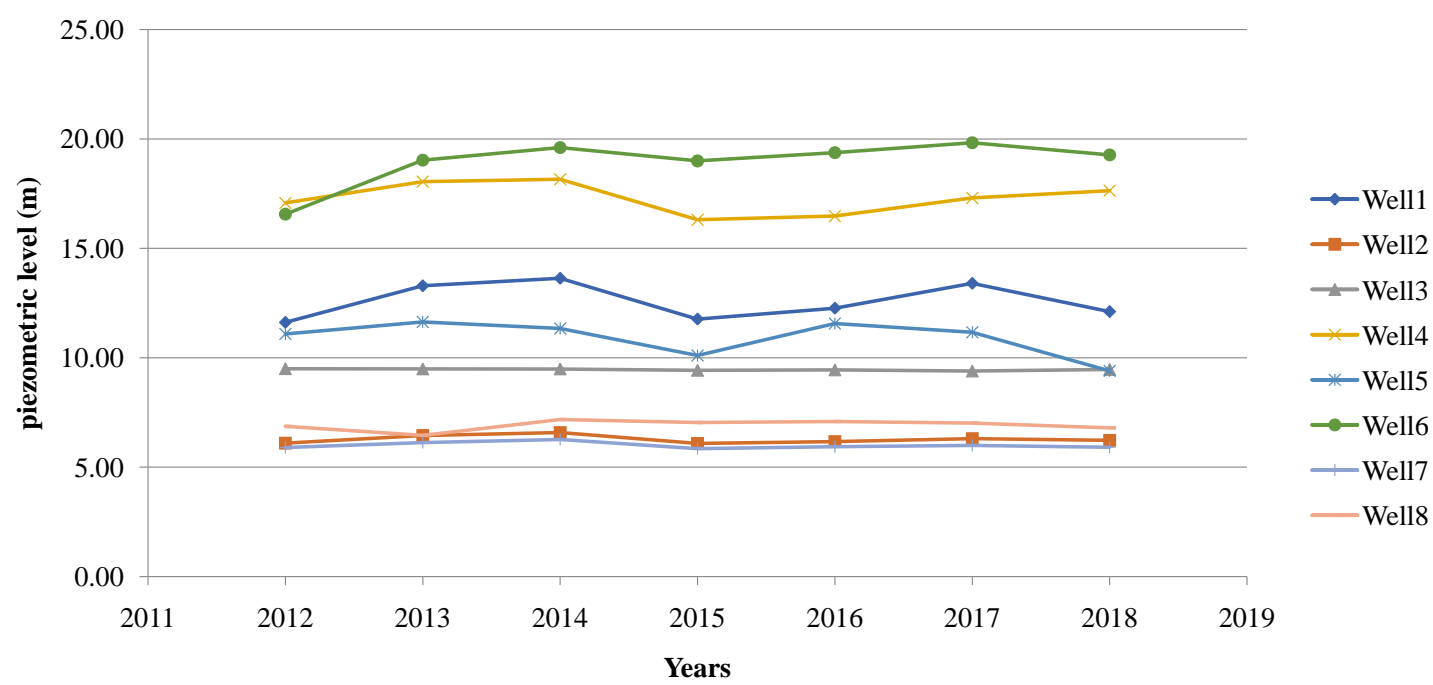

Figure 9. Evolution of the piezometric level of the quaternary water table (2012-2018).

sometimes difficult. So, we chose clean, noise-free images that don't require too much atmospheric correction to view them. The approach followed is summarized in Figure 10.

Three main stages have been distinguished:

The first stage concerns the corrections of the radiometric anomalies specific to the sensor (Radiometric Correction), the effects of the atmosphere (Atmospheric Correction) as well as spatial improvements (Spatial enhancement);

The second stage is mainly focused on processing the images and calculating the NDVI vegetation index (Rouse et al., 1973; Tucker, 1979). The formula (1) 


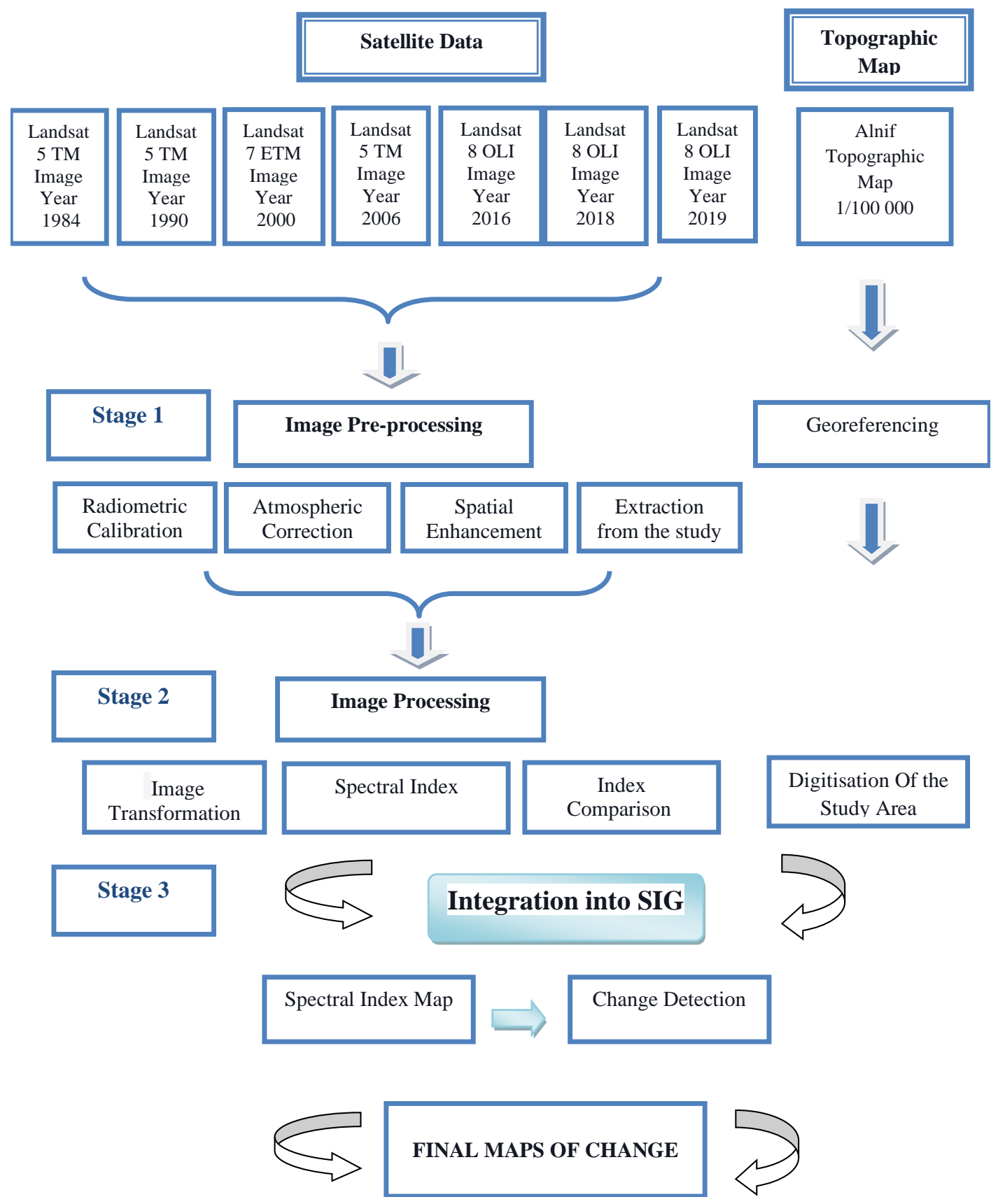

Figure 10. Flowchart of the adopted methodology.

used for this calculation is as follows:

$$
\mathrm{NDVI}=(\mathrm{PIR}-\mathrm{RBand}) /(\mathrm{PIR}-\mathrm{RBand})
$$

with PIR: Reflectance in the Near InfraRed and R: Reflectance in the Red.

This index takes values between 1 and -1 . Negative values correspond to surfaces such as water or clouds for which the reflectance in the red is greater than that of the near infrared. For bare soils, the reflectance being roughly of the same order of magnitude in the red and near infrared, the NDVI therefore has values close to 0 . Plant formations, for their part, have positive NDVI values, generally 
included between 0.3 and 1 . The highest values correspond to the densest covers.

The third stage is the integration of this index into a GIS for spatial and statistical analysis. Detection of changes in the GIS is the method used to understand how a given area has changed between two or more time periods (Singh, 1989; Li et al., 2020; Khalis et al., 2021; Measho et al., 2021). In our study, we tested this technique for the NDVI index in order to construct a map of the change in the land cover from multitemporal images. The formula (2) used for the development of change maps is as follows (Singh, 1989; Li et al., 2020; Khalis et al., 2021; Measho et al., 2021):

$$
\operatorname{NDVI}(n)(n+1)=\operatorname{NDVI}(n+1)-\operatorname{NDVI}(n)
$$

with n: year.

\section{Results and Discussion}

The use of remote sensing and GIS techniques makes it possible to highlight the changes made in the vegetation cover in the Bour El Khourbat study area.

\subsection{Spatiotemporal Variability of the Vegetation in Bour El Khourbat}

The calculation of the NDVI vegetation index of the satellite images covering the so-called Bour El Khourbat extension for the month of May of the years 1984, 1990, 2000, 2006, 2016, 2018 and 2019 allowed us to visualize the variation of plant cover over time (Figure 11).

According to NDVI maps, the degree of evolution of the vegetation cover in the extension of Bour El Khourbat from 1984 to 2019 is illustrated in Figure 12.

Observation of NDVI maps of the vegetated surfaces of Bour El Khourbat shows that from 1984 to 2000 , the vegetation cover was decreasing. This can be explained by the period of droughts recorded during these years. Note that the irrigation system during this time was made up of the gravity system only.

Before that, the year 1984 shows a large area despite the well-known climatic drought all over Morocco. This can be explained by a slightly favorable underground hydrology (hydrological drought not and/or not very evident).

Between 2006 and 2016, the vegetation cover experienced an increase and a significant extension towards the South-East of the zone. Indeed, precipitation experienced during this period a significant increase. Thus, farmers in the area have also started to use water-saving techniques in irrigation: Drop by Drop and the construction of geomembrane water storage basins. These techniques are all subsidized by the Moroccan government under the Green Morocco Plan.

Between 2016 and 2018, there was a decrease in the extension of the area of vegetation despite the use of water saving techniques (Drip/Storage basins). This situation can be explained by the use of excessive solar pumping by some farmers, which has led to the overexploitation of the water table and may have impacted the water resources of other unequipped farmers with photovoltaic solar panels. Note that the area, during this period, was less rainy. 


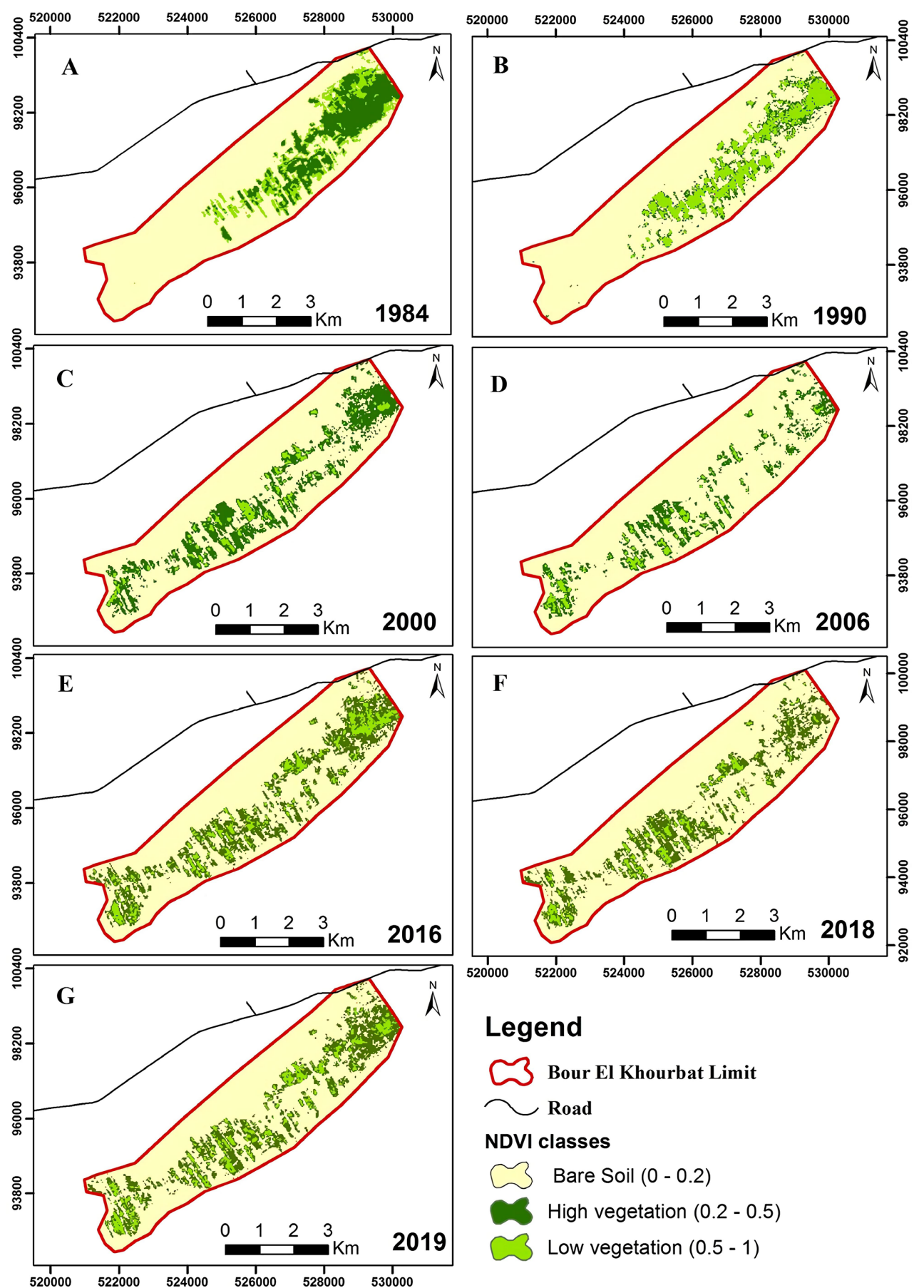

Figure 11. NDVI classes maps from 1984 to 2019. A 1984; B 1990; C 2000; D 2006; E 2016; F 2018; G 2019.

\subsection{Technical Application "Change Detection"}

In order to understand the change observed in the vegetation cover, we are testing the "Change detection" technique for the NDVI index between the years 1984 and 2019 calculated from Landsat images. The results obtained are in the form of a map change in vegetation cover from multi-temporal images.

Figure 13 represents two change maps resulting from the calculation of "Change 


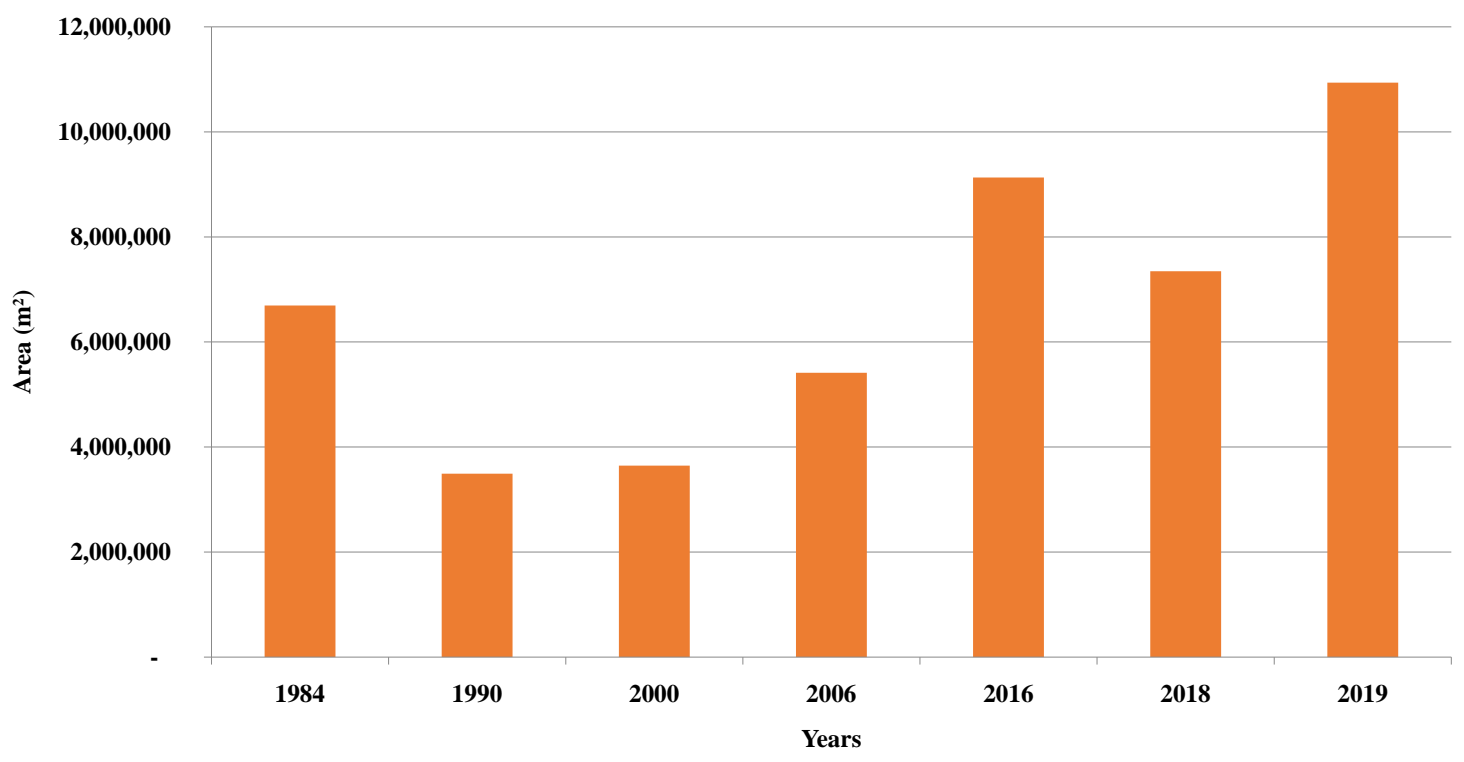

Figure 12. Dynamics of vegetation surfaces from 1984 to 2019.

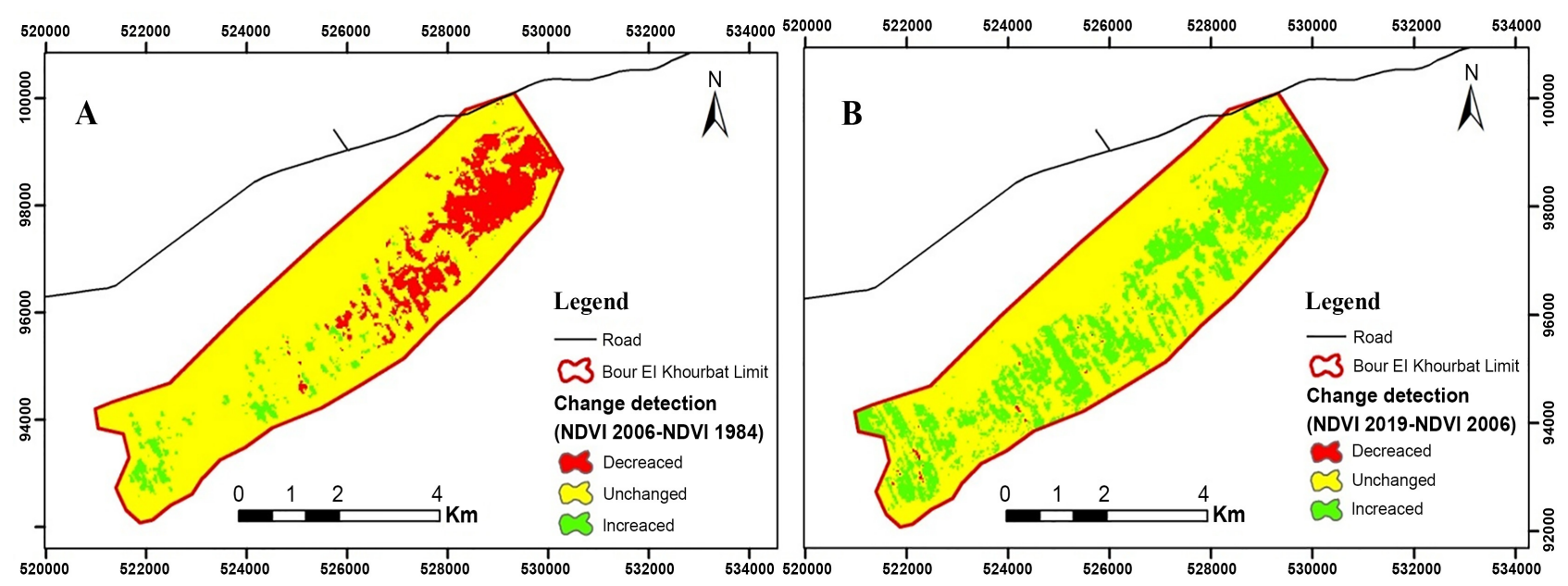

Figure 13. Detection of change in plant cover in Bour El Khourbat. (A) From 1984 to 2006; (B) From 2006 to 2019.

detection" under a GIS between the years 1984 and 2006 and between the years 2006 and 2019. These two periods represent two different types of practices, before and after the year 2004 (after modification of water resource use practices).

On the resulting maps, there are generally three classes:

Pixels with a value greater than 0 reflect areas that have experienced vegetation enrichment from 2004 (green color).

Pixels with a value of 0 are the areas that have not experienced any change (yellow to orange color).

The pixels with a negative value correspond to the places where the vegetation cover has regressed (red color).

Between 1984 and 2006, the first change map shows a regression of the vegetation in the North-West of the zone and a progression of this towards the South-East. This progression can be explained by farmers' capture of fissure wa- 
ter from the Paleozoic basement.

Between 2006 and 2019, the second change map clearly shows a return of homogeneous vegetation throughout the area. This situation can be explained by the irrigation schemes introduced throughout Bour El Khourbat.

Analysis of the NDVI maps as well as those of change shows that between 1984 and 2006, we observed a variation in the vegetation cover in terms of area with a transition of it towards the South-East of the zone. Between 2006 and 2019, the vegetation cover doubled over the entire oasis (Figure 12). The North-West zone again shows an increase in the vegetation cover making the vegetation homogeneous in the zone. This change is linked on one hand to climate and hydrological conditions: variation in precipitation (dry years, lack of flooding and therefore of supply and recharge of the water table, etc.) and on the other hand to hydro-agricultural developments, in place by the Moroccan government namely:

- Installation of the localized "Drop by Drop" irrigation system which was introduced in the region from 2005-2006. This system was initially adopted by two farmers (pilot project, international fund for agricultural development project) before being developed more and more by the other remaining farmers in the area;

- Commissioning in 2013 of the upstream diversion of Bour El Khourbat on the Oued Ferkla (Khourbat Dam), built under the Millennium Challenge Account Program between 2010 and 2013 and the installation of a network of canals. Irrigation derived from it intended for the irrigation of palm groves downstream. The opening and construction work of these canals were carried out simultaneously with the dam and they continued until 2016 for the construction of certain structures and sections of canals.

\section{Conclusion}

After having highlighted the changes during almost 35 years, produced at the level of land use in the modern oasis of Bour El Khourbat also known as an extension zone compared to the traditional oasis, we can say that the context physical nature of the area is characterized by fragility and precariousness: unfavorable geology and geomorphological position, low to very low precipitation, very limited water resources, sometimes violent winds, above all lack of agricultural data on the area, etc.

The stability of the population of Bour El Khourbat in particular and that of the Ferkla oasis in general (more than 40,000 individuals) requires an integrated management of water in this extension area which is located in a strategic position for the entire oasis of Ferkla.

Despite the efforts made, the situation remains precarious, very vulnerable and very worrying. Sustainability requires more efforts and consultation on the use and management of water (surface and underground). Water withdrawals from the aquifer must be done according to the capacities of the aquifer throughout the sub-basin by drawing inspiration and innovating what local communities 
have been doing for millennia. Thus, a participatory groundwater contract validated by all stakeholders, for example, to ensure its application and rigorous monitoring could mitigate these threats, which are increasingly strong and accentuated by climate change.

Farmers in the area are therefore led to save and enhance the value of water, which is already scarce, by opting in particular for good practices (generalization of water-saving techniques, namely drop by drop, rigorous control of the quantities of water storage in basins, construction of artificial water supply thresholds, efficient and effective use of flood water for irrigation, enhancement of agricultural production and protection of soils against degradation ...).

\section{Acknowledgements}

We gratefully thank to the Hydraulic Agency of Guir-Ziz-Rheris Basins for the disposability of the hydroclimatic data.

\section{Conflicts of Interest}

The authors declare no conflicts of interest regarding the publication of this paper.

\section{References}

ABHGZR (Agence du Bassin Hydraulique du Guir Ziz Rheris) (2011). Actualisation du plan directeur d'aménagement intégré des ressources en eau des bassins de Guir-Rhrés-Ziz et Maider. Errachidia.

Baki, S., Hilali, M., Kacimi, I., \& Mahboub, A. (2016). Hydrogeological Characterization and Mapping of Water Resources in the Rheris Watershed (Southeast Morocco). Bulletin de l'Institut Scientifique, Section Sciences de la Terre, 38, 29-43.

Boudad, L., \& Kabiri, L. (2002). Désertification et crise de quelques oasis dans les bassins versants de Ziz et Gheris (Errachidia, Maroc). Revue de Géographie du Maroc, 20, 97-106.

Du Dresnay, R., Hindermeyer, J., Emberger, A. et al. (1988). Carte géologique du Maroc au 1/200,000. Feuille Todgha-Ma'de.

Kabiri, L. (2005). Impact des changements climatiques et anthropiques sur les ressources en eau dans l'Oasis de Ferkla (Tinjdad, Goulmima, Errachidia, Maroc).

https://ma.chm-cbd.net/fes-meknes/liens/bibliotheque/publication/oasis.pdf/download lar/1/oasis.pdf

Khalis, H., Sadiki, A., Jawhari, F., Mesrar, H., Azab, E., Gobouri, A.A. et al (2021). Effects of Climate Change on Vegetation Cover in the Oued Lahdar Watershed, Northeastern Morocco. Plants, 10, Article No. 1624. https://doi.org/10.3390/plants10081624

Li, G., Li, L., Lu, D., Guo, W., \& Kuang, W. (2020). Mapping Impervious Surface Distribution in China Using Multi-Source Remotely Sensed Data. GIScience and Remote Sensing, 57, 543-552. https://doi.org/10.1080/15481603.2020.1744240

Margat, J. (1958). Les recherches hydrogéologiques et l'exploitation des eaux souterraines au Tafilalt. Mines et Géologie, No. 4, 43-68.

Measho, S., Chen, B., Pellikka, P., Guo, L., Zhang, H., Cai, D. et al. (2021). Assessment of Vegetation Dynamics and Ecosystem Resilience in the Context of Climate Change and 
Drought in the Horn of Africa. Remote Sensing, 13, Article No. 1668.

https://doi.org/10.3390/rs13091668

RGPH (Recensement général de la Population et de l'Habitat) (2014). Recensement général de la population et de l'habitat 2004 et 2014. http://www.hcp.ma

Rouse, J.W., Hass, R. H., Schell, J. A., \& Deering, D. W. (1973). Monitoring Vegetation Systems in the Great Plains with ERTS. NASA Special Publication, 351, 309.

Ruhard, J. P. (1977). Ch. 44: Le bassin quaternaire du Tafilalt. In Ressources en eau du Maroc (pp. 352-415). Service géologique du Maroc.

Singh, A. (1989). Review Article: Digital Change Detection Techniques Using Remotely-Sensed Data. International Journal of Remote Sensing, 10, 989-1003. https://doi.org/10.1080/01431168908903939

Tucker, C. J. (1979). Red and Photographic Infrared Linear Combinations for Monitoring Vegetation. Remote Sensing of Environment, 8, 127-150.

https://doi.org/10.1016/0034-4257(79)90013-0 